\title{
Higher bypass temperature correlates with increased white cell activation in the cerebral microcirculation
}

\author{
Vesa Anttila, $M D^{\mathrm{a}, \mathrm{d}}$ \\ Ikuo Hagino, MDa \\ David Zurakowski, $\mathrm{PhD}^{\mathrm{b}}$ \\ Hart G. W. Lidov, MDc \\ Richard A. Jonas, MDa
}

From the Departments of Cardiovascular Surgery, ${ }^{\mathrm{a}}$ Biostatistics, ${ }^{\mathrm{b}}$ and Pathology, ${ }^{\mathrm{c}}$ Children's Hospital Boston, Harvard Medical School, Boston, Mass, and the Department of Surgery, ${ }^{\mathrm{d}}$ University Hospital of Oulu, Oulu, Finland.

Supported by a grant from the National Institutes of Health (2R01HL60922). Dr Anttila was supported in part by The Academy of Finland and The Paavo Nurmi Foundation

Read at the Eighty-third Annual Meeting of The American Association for Thoracic Surgery, Boston, Mass, May 4-7, 2003.

Received for publication June 13, 2003; revisions received Oct 10, 2003; accepted for publication Jan 8, 2004.

Address for reprints: Richard A. Jonas, MD, Department of Cardiac Surgery, Children's Hospital Boston, 300 Longwood Ave, Boston MA 02115 (E-mail: richard.jonas@TCH.harvard.edu).

J Thorac Cardiovasc Surg 2004;127:1781-8 $0022-5223 / \$ 30.00$

Copyright $\odot 2004$ by The American Association for Thoracic Surgery

doi:10.1016/j.jtcvs.2004.01.037
Objective: Cardiopulmonary bypass induces a systemic inflammatory response, which in turn promotes a cascade of leukocyte and endothelial cell activity. We investigated whether differences in bypass temperature and flow rate affect endothelial cell and leukocyte adhesion in the cerebral microcirculation.

Methods: Thirty-six piglets $(13.0 \pm 1.1 \mathrm{~kg})$ had a cranial window placed over the parietal cortex to evaluate the microcirculation by means of intravital microscopy. Animals were cooled to a temperature of $15^{\circ} \mathrm{C}, 25^{\circ} \mathrm{C}$, or $34^{\circ} \mathrm{C}$ on cardiopulmonary bypass with hematocrit levels of $20 \%$ or $30 \%$ by using pH-stat management, followed by 60 minutes of reduced flow $\left(10,25\right.$, or $\left.50 \mathrm{~mL} \cdot \mathrm{kg}^{-1} \cdot \mathrm{min}^{-1}\right)$. Rhodamine staining was used to observe adherent and rolling leukocytes in postcapillary venules.

Results: Higher bypass temperature correlated with significantly more adherent and rolling leukocytes during the full 60 minutes of low-flow bypass $(P<.05)$. Poisson regression revealed more adherent leukocytes at $34^{\circ} \mathrm{C}$ than at $15^{\circ} \mathrm{C}$ and at a flow rate of $10 \mathrm{~mL} \cdot \mathrm{kg}^{-1} \cdot \mathrm{min}^{-1}$ compared with a flow rate of $50 \mathrm{~mL} \cdot \mathrm{kg}^{-1} \cdot \mathrm{min}^{-1}$. There was an inverse correlation between flow rate and the number of adherent and rolling leukocytes at 30, 45, and 60 minutes of low-flow bypass $(P<.05)$. Temperature was a multivariable predictor of histologic score, with greater neurologic damage found after bypass at $34^{\circ} \mathrm{C}(P<.01)$.

Conclusions: Leukocyte activation in cerebral microcirculation is increased with higher temperature and lower flow rate, suggesting that these variables influence the inflammatory response during cardiopulmonary bypass.

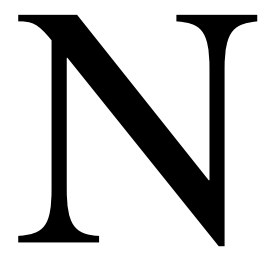
eurologic injury can result from cardiopulmonary bypass (CPB), and therefore it is of paramount concern in cardiovascular surgery. The harmful effects of CPB are related to many factors, including activation of the complement and coagulation systems and stimulation of cytokine production, leukocyte activation, and endothelial dysfunction, which are collectively known as the systemic inflammatory response.

Adherence of leukocytes to endothelial cells is triggered by contact with the foreign surface of the extracorporeal circuit and mechanical shear forces. Circulating leukocytes make transient contact to selectins on endothelial cells, which line the vessel wall. After contact, leukocytes roll along the vessel wall at a greatly reduced velocity. Adhesion of leukocytes to the vessel wall is mediated by the leukocyte $\beta 2$ integrins and endothelial adhesion molecules, including the immunoglobulin family. ${ }^{1}$ Subsequent transendothelial migration of leukocytes is accompanied by functional blood-brain barrier disruption mediated in part by enzymes released from activated leukocytes. ${ }^{2}$ 


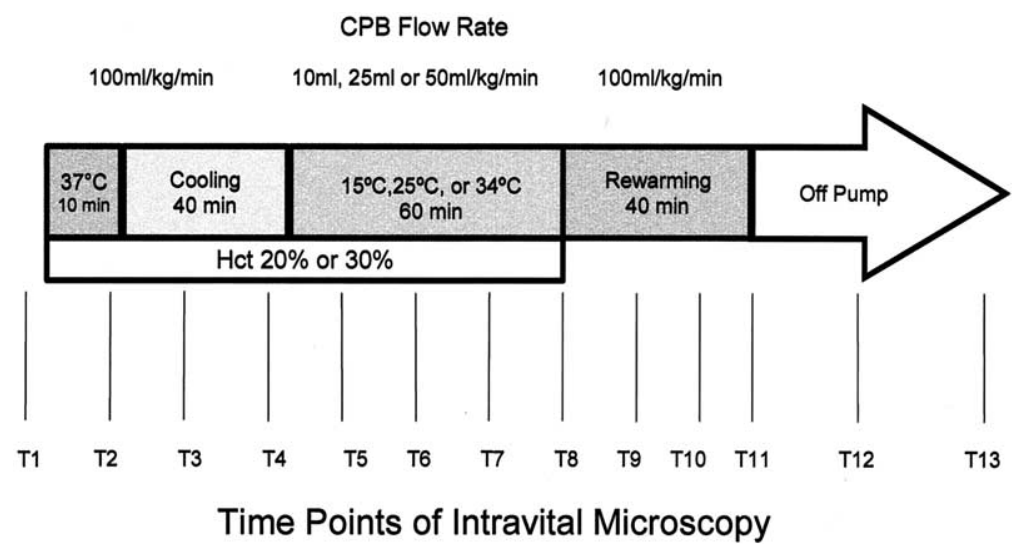

Figure 1. Experimental protocol. During the low-flow period, perfusion parameters included 2 hematocrit levels $(20 \%$ and $30 \%), 3$ temperatures $\left(15^{\circ} \mathrm{C}, 25^{\circ} \mathrm{C}\right.$, or $\left.34^{\circ} \mathrm{C}\right)$, and $3 \mathrm{flow}$ rates $\left(10,25\right.$, or $\left.50 \mathrm{~mL} \cdot \mathrm{kg}^{-1} \cdot \mathrm{min}^{-1}\right)$. Intravital microscopy was performed at 13 time points starting at baseline before CPB. During bypass, intravital microscopy was recorded every 15 minutes, and after weaning from pump, it was performed at 30 and 60 minutes. Hct, Hematocrit.

Intravital microscopy is a technique that allows real-time observation of the microcirculation, including white cell and endothelial activation demonstrated by rolling and adherent leukocytes. We have previously reported development of a piglet model using intravital microscopy, allowing direct visualization of the cerebral microcirculation during CPB. ${ }^{3}$ The present study was designed to investigate the effects of hypothermia, hematocrit level, and flow rate in modulating the inflammatory response to bypass, with particular attention to the cerebral microcirculation with the goal of defining minimum safe conditions of bypass rather than optimal conditions. We hypothesized that a higher bypass temperature and lower bypass flow rate would increase leukocyte activation.

\section{Material and Methods}

\section{Surgical Preparation}

Thirty-six juvenile (6-7 weeks old) Yorkshire piglets with a mean body weight of $13.0 \pm 1.1 \mathrm{~kg}$ were included in the study. All animals received humane care in accordance with the "Principles of Laboratory Animal Care" formulated by the National Society for Medical Research and the "Guide for the Care and use of Laboratory Animals" prepared by the Institute of Laboratory Animal Resources, National Research Council, and published by the National Academy Press (revised 1996).

After sedation with an intramuscular injection of ketamine (20 $\mathrm{mg} / \mathrm{kg}$ ) and xylazine $(4 \mathrm{mg} / \mathrm{kg})$, the piglets were intubated and ventilated with $21 \%$ oxygen at a respiratory rate of between 18 and 20 breaths/min to achieve an arterial $\mathrm{PCO}_{2}$ of 35 to $40 \mathrm{~mm} \mathrm{Hg}$. After induction with fentanyl $(25 \mu \mathrm{g} / \mathrm{kg}$ administered intravenously), anesthesia was maintained with continuous infusion of fentanyl $\left(25 \mu \mathrm{g} \cdot \mathrm{kg}^{-1} \cdot \mathrm{h}^{-1}\right)$, midazolam $\left(0.2 \mathrm{mg} \cdot \mathrm{kg}^{-1} \cdot \mathrm{h}^{-1}\right)$, and pancuronium $\left(0.2 \mathrm{mg} \cdot \mathrm{kg}^{-1} \cdot \mathrm{h}^{-1}\right)$. Temperature probes were placed into the esophagus and rectum. A catheter (19G Intracath;
Becton Dickinson, Sandy, Utah) was inserted in the left superficial femoral artery and advanced into the abdominal aorta for continuous blood pressure monitoring. For anesthesia infusion, a catheter (19G Intracath, Becton Dickinson) was introduced through the right femoral vein into the inferior vena cava. After systemic heparinization (300 IU/ $\mathrm{kg}$ administered intravenously) and a right anterolateral thoracotomy in the third intercostal space, an $8 \mathrm{~F}$ arterial cannula (Bio-Medicus; Medtronic Inc, Eden Prairie, Minn) was inserted through the right femoral artery into the abdominal aorta, and a 28F cannula (Harvey; Bard, Tewksbury, Mass) was inserted directly into the right atrium for CPB. The piglets were positioned prone in a stereotactic frame, and a cranial window (15 $\times 15 \mathrm{~mm}$ ) was created over the parietal cerebral cortex with an electric drill. After incision of the dura, the surface (pial) vessels were visualized. The cranial window was closed with a glass cover slip.

\section{Experimental Protocol}

Thirty-six piglets were randomized according to the experimental protocol. The study protocol is depicted in Figure 1. A temperature of either $15^{\circ} \mathrm{C}, 25^{\circ} \mathrm{C}$, or $34^{\circ} \mathrm{C}$ was maintained during the low-flow period. Flow rates of 10,25 , or $50 \mathrm{~mL} \cdot \mathrm{kg}^{-1} \cdot \mathrm{min}^{-1}$ were used during the low-flow period. The hematocrit level was maintained at either $20 \%$ or $30 \%$ during the low-flow period. Every combination of temperature, flow rate, and hematocrit level $(3 \times 3 \times 2$ $=18$ settings) was performed in 2 separate experiments.

Arterial pressure was monitored continuously throughout each experiment and was recorded every 15 minutes. Hemoglobin, hematocrit, glucose, lactate, $\mathrm{Po}_{2}, \mathrm{PCO}_{2}$, and $\mathrm{pH}$ were measured every 15 minutes during $\mathrm{CPB}$, at 30 minutes after $\mathrm{CPB}$, and once an hour until extubation with a blood gas analyzer (Stat Profile 9; Nova, Waltham, Mass). Systemic white blood cell counts (WBCs) were obtained at baseline, at the end of cooling, at the end of rewarming, and 60 minutes after weaning from $\mathrm{CPB}$. 


\section{CPB Technique}

The CPB circuit consisted of a roller pump (Cardiovascular Instrument Corp, Wakefield, Mass), membrane oxygenator (Minimax; Medtronic Inc, Anaheim, Calif), and sterile tubing with a 40- $\mu \mathrm{m}$ arterial filter. Fresh whole blood from a donor pig, drawn on the operative day, was transfused into the prime as required to adjust the hematocrit level to either $20 \%$ or $30 \%$. Methylprednisolone $(30 \mathrm{mg} / \mathrm{kg})$, furosemide $(0.25 \mathrm{mg} / \mathrm{kg})$, sodium bicarbonate $7.4 \%(10 \mathrm{~mL})$, and cephazolin sodium $(25 \mathrm{mg} / \mathrm{kg})$ were added to the prime before the start of $\mathrm{CPB}$. The $\mathrm{pH}$-stat strategy was used (sweep gas $95 \% \mathrm{O}_{2} / 5 \% \quad \mathrm{CO}_{2}$ ). The gas flow was adjusted to achieve an arterial $\mathrm{PCO}_{2}$ of 40 to $45 \mathrm{~mm} \mathrm{Hg}$ (corrected to nasopharyngeal temperature). After baseline recordings, CPB with a flow rate of $100 \mathrm{~mL} \cdot \mathrm{kg}^{-1} \cdot \mathrm{min}^{-1}$ was started, and the animals were perfused for 10 minutes at normothermia (esophageal temperature, $37^{\circ} \mathrm{C}$ ). Ventilation was stopped after the establishment of $\mathrm{CPB}$. The piglets underwent 40 minutes of cooling during $\mathrm{CPB}$ to an esophageal temperature of either $15^{\circ} \mathrm{C}, 25^{\circ} \mathrm{C}$, or $34^{\circ} \mathrm{C}$. After cooling, a low-flow perfusion flow rate of 10,25 , or $50 \mathrm{~mL} \cdot \mathrm{kg}^{-1}$ $\cdot \min ^{-1}$ was initiated for 60 minutes. Before rewarming, sodium bicarbonate $7.4 \%(10 \mathrm{~mL})$, methylprednisolone $(30 \mathrm{mg} / \mathrm{kg})$, furosemide $(0.25 \mathrm{mg} / \mathrm{kg})$, and mannitol $(0.5 \mathrm{~g} / \mathrm{kg})$ were administered into the pump. During 40 minutes of rewarming, animals were warmed to $37^{\circ} \mathrm{C}$ with a flow rate of $100 \mathrm{~mL} \cdot \mathrm{kg}^{-1} \cdot \mathrm{min}^{-1}$. The heart was defibrillated if necessary at an esophageal temperature of $30^{\circ} \mathrm{C}$. Ventilation $(100 \%$ oxygen) was started 10 minutes before weaning from CPB. Protamine $(5 \mathrm{mg} / \mathrm{kg}$ ) was administered intravenously after the animal was hemodynamically stable. The wounds were closed in a sterile fashion.

Animals remained sedated and paralyzed by a continuous infusion of fentanyl $\left(50 \mu \mathrm{g} \cdot \mathrm{kg}^{-1} \cdot \mathrm{h}^{-1}\right)$, midazolam $\left(0.2 \mathrm{mg} \cdot \mathrm{kg}^{-1}\right.$ $\left.\cdot \mathrm{h}^{-1}\right)$, and pancuronium $\left(0.2 \mathrm{mg} \cdot \mathrm{kg}^{-1} \cdot \mathrm{h}^{-1}\right)$ and were mechanically ventilated and monitored continuously for 12 hours after the operation. The chest tubes were removed, and the animals were extubated.

\section{Intravital Microscopy}

An epifluorescence microscope (Model MZFL III; Leica, Heerbrugg, Switzerland) with a 100-W mercury gas discharge lamp equipped with a rapid filter exchanger was placed over the cranial window. The microscope was mounted on a surgical stand (Wild Heerbrugg, Switzerland) to facilitate the use of intravital microscopy in this large-animal model. The microscope included 2 sets of filters: a blue filter set (450-490 nm excitation/>515-nm emission wavelength) for visualization of fluorescein fluorescence and a green filter set (536- $556 \mathrm{~nm}$ excitation/>590-nm emission wavelength) for visualization of rhodamine-labeled leukocytes.

The microscope images from the charge-coupled device video camera (Dage-300-RC; Dage-MTI) were time stamped with a time-code generator (VTG-33, For-A). The images were transferred to a high-resolution 12-inch monitor (Dage HR-1000; DageMTI, Michigan City, Ind) and videotaped. A Scion LG-3 frame grabber card (Scion Corp, Frederick, Md) and computer-assisted image analysis system (NIH Image; National Institutes of Health, Bethesda, Md) were used for subsequent offline analysis. The final magnification on the monitor was $400 \times$.

Plasma was labeled with $1 \mathrm{~mL}$ of fluorescein isothiocyanateDextran 5\% (150 kd; Sigma Chemical, St Louis, Mo) before each subsequent measurement to visualize microvascular perfusion. The fluorescein isothiocyanate fluorescence was excited by using the blue filter set. The plasma became highlighted, and the red blood cells appeared dark (negative contrast).

For the assessment of leukocyte-endothelial cell interactions, the circulating leukocytes were labeled with $2 \mathrm{~mL}$ of rhodamine-6G 0.2\% (Sigma Chemical). The number of adherent (adherent leukocytes/100- $\mu \mathrm{m}$ vessel length) and rolling leukocytes (rollers/100- $\mu \mathrm{m}$ vessel length per minute) in 20 - to $30-\mu \mathrm{m}$-diameter postcapillary venules were observed. A green filter set was used to excite rhodamine fluorescence.

Intravital microscopy was performed at baseline; at 10 minutes of normothermic CPB; at 20 minutes of cooling; at the end of cooling; at 15, 30, and 45 minutes and at the end of the low-flow period; at 15, 30, and 40 minutes of reperfusion; and at 30 and 60 minutes after weaning from CPB (Figure 1). The duration of epi-illumination was limited to less than 1 minute to avoid thermal injury of tissue. The epi-illumination of brain tissue was always stopped between video recordings.

\section{Postoperative Evaluation}

After the operation, neurologic and behavioral evaluations were performed at 24-hour intervals by a senior veterinarian blinded to the experimental protocol beginning on postoperative day (POD) 1. Neurologic scoring was adapted from the neurologic deficit score $(500=$ brain death, $0=$ normal $)$ and overall performance category $(5=$ brain death, $4=$ coma, $3=$ severe impairment, $2=$ moderate impairment, $1=$ normal). ${ }^{4}$

\section{Histopathologic Analysis}

On POD 4, all piglets were sedated by means of intramuscular induction with ketamine $(20 \mathrm{mg} / \mathrm{kg})$ and xylazine $(4 \mathrm{mg} / \mathrm{kg})$ and anesthetized with intravenous fentanyl $(50 \mu \mathrm{g} / \mathrm{kg})$. After a midline sternotomy, heparin $(300 \mathrm{IU} / \mathrm{kg}$ ) was administered, and a cannula was inserted into the left common carotid artery. The aortic arch was clamped, and $1 \mathrm{~L}$ of Plasmalyte solution (Baxter) was infused through the left common carotid artery. Blood was suctioned from the superior vena cava until the perfusate was clear of blood. Then $3 \mathrm{~L}$ of $10 \%$ formalin solution was perfused through the brain in the same manner to accomplish a perfusion fixation. The entire head of the piglet was immersed in $10 \%$ formalin for a week, and the brain was harvested and fixed with $10 \%$ formalin solution for the histologic assessment. ${ }^{5}$

The preparation of the cerebral specimens and the details of analyses have been described previously. ${ }^{5,6}$ Histologic damage was scored by using the following criteria: 5 , cavitated lesions with necrosis; 4, significant damage to neurons; 3, large clusters of injured neurons; 2 , small clusters of damaged neurons; 1 , isolated neuronal damage; and 0 , normal. A single neuropathologist (H.G.W.L.) examined all specimens in a blinded fashion.

\section{Statistical Analysis}

Continuous variables are expressed as means \pm SD. The Kolmogorov-Smirnov test indicated that the variables followed a normal distribution. Therefore repeated-measures analysis of variance (ANOVA) was used to evaluate changes over time and to compare rates of change between the groups. One-way ANOVA with Bonferroni $t$ tests was used to detect differences between the experi- 
mental groups at different time points. The nonparametric Spearman $\rho$ coefficient was used to measure the correlation between intravital microscopy data and temperature, flow rate, and hematocrit levels. Poisson regression was applied to determine the effects of temperature, flow rate, and hematocrit level on the number of leukocytes. ${ }^{7}$ Multivariable logistic regression was used to determine the independent predictors of neurologic damage by treating the histologic score as a binary outcome ( 0 , no damage; 1 , damage), with the odds ratio calculated as a measure of risk. ${ }^{8}$ All reported $P$ values are 2-tailed. The software package used for statistical analysis was SPSS version 11.0 for Windows (SPSS Inc, Chicago, Ill).

\section{Results}

Baseline measurements (before CPB) indicated no significant differences between experimental groups regarding hematocrit levels, blood gases, systemic leukocyte counts, whole-body lactate levels, numbers of rolling or adherent leukocytes, and cerebral microvascular diameters.

\section{White Blood Cell Counts}

The number of circulating leukocytes, as measured on the basis of WBCs, did not differ in terms of protocol settings at baseline (mean, $15.3 \pm 4.8 \times 1000 / \mu \mathrm{L})$. At the end of the 40-minute cooling period, WBCs decreased to $6.6 \pm 2.8$ $\left(15^{\circ} \mathrm{C}\right.$ group), $9.5 \pm 3.1\left(25^{\circ} \mathrm{C}\right.$ group $)$, and $12.2 \pm 3.7 \times$ $1000 / \mu \mathrm{L}\left(34^{\circ} \mathrm{C}\right.$ group). ANOVA indicated differences between the $15^{\circ} \mathrm{C}$ and $25^{\circ} \mathrm{C}$ groups $(P<.05)$ and between the $15^{\circ} \mathrm{C}$ and $34^{\circ} \mathrm{C}$ groups $(P<.001)$. At the end of rewarming, the mean number of circulating leukocytes varied according to flow rate: $13.1 \pm 3.8$ at $10 \mathrm{~mL} \cdot \mathrm{kg}^{-1} \cdot \mathrm{min}^{-1}, 15.3 \pm 3.2$ at $25 \mathrm{~mL} \cdot \mathrm{kg}^{-1} \cdot \mathrm{min}^{-1}$, and $11.8 \pm 2.0$ at $50 \mathrm{~mL} \cdot \mathrm{kg}^{-1}$ $\cdot \min ^{-1}$. The difference between the 25 and $50 \mathrm{~mL} \cdot \mathrm{kg}^{-1}$. $\min ^{-1}$ groups was significant $(P<.05)$. At the end of the observation period (ie, 60 minutes after weaning from
CPB), there were no differences in WBCs between study protocols (mean, $13.2 \pm 4.9 \times 1000 / \mu \mathrm{L}$; Figure 2 ).

\section{Leukocyte-Endothelial Cell Interactions}

At the end of the cooling period, more adherent leukocytes were found at $34^{\circ} \mathrm{C}$ compared with at $15^{\circ} \mathrm{C}(P=.02)$ and $25^{\circ} \mathrm{C}(P=.001)$ in postcapillary venules (Table 1$)$. At that time point, temperature was positively correlated with the number of adherent leukocytes (Spearman $\rho=0.35 ; P<$ $.05)$.

Multivariable analysis showed that temperature and flow rate were independent predictors of the number of rolling and adherent leukocytes, although hematocrit level was not. Throughout the 60 minutes of low-flow bypass, a significantly greater number of rolling leukocytes were found at $34^{\circ} \mathrm{C}$ compared with at $15^{\circ} \mathrm{C}(P<.05)$ and between $34^{\circ} \mathrm{C}$ and $25^{\circ} \mathrm{C}$ at 15,30 , and 45 minutes $(P<.05)$.

Numbers of adherent leukocytes were greater during the entire low-flow bypass at $34^{\circ} \mathrm{C}$ compared with at $15^{\circ} \mathrm{C}(P<$ $.05)$. In addition, more adherent leukocytes were found at 15 and 30 minutes during the low-flow period with a temperature of $34^{\circ} \mathrm{C}$ compared with a temperature of $25^{\circ} \mathrm{C}(P<$ $.05)$. A greater number of rolling leukocytes were found at 45 and 60 minutes during the low-flow period with a flow rate of $10 \mathrm{~mL} \cdot \mathrm{kg}^{-1} \cdot \mathrm{min}^{-1}$ compared with a flow rate of $50 \mathrm{~mL} \cdot \mathrm{kg}^{-1} \cdot \mathrm{min}^{-1}(P<.05)$. Significantly more adherent leukocytes were found at 30, 45, and 60 minutes during the low-flow period at a flow rate of 10 and $25 \mathrm{~mL} \cdot \mathrm{kg}^{-1}$ $\cdot \min ^{-1}$ compared with a flow rate of $50 \mathrm{~mL} \cdot \mathrm{kg}^{-1} \cdot \mathrm{min}^{-1}$ (Tables 1 and 2).

Temperature was positively correlated with the number of adherent and rolling leukocytes during the full $60 \mathrm{~min}$ utes of reduced-flow bypass (Spearman $\rho=0.36-0.62, P<$ 
TABLE 1. Number of rolling and adherent leukocytes by temperature, hematocrit, and total histologic scores

\begin{tabular}{|c|c|c|c|c|c|c|c|c|c|c|}
\hline \multirow{2}{*}{$\begin{array}{l}\text { Temperature and } \\
\text { hematocrit during low- } \\
\text { flow bypass }\end{array}$} & \multirow[b]{2}{*}{$\mathbf{N}$} & \multirow[b]{2}{*}{ Baseline } & \multirow{2}{*}{$\begin{array}{l}\text { End of } \\
\text { cooling }\end{array}$} & \multicolumn{4}{|c|}{ Low-flow bypass } & \multirow{2}{*}{$\begin{array}{c}\text { End of } \\
\text { rewarming }\end{array}$} & \multirow{2}{*}{$\begin{array}{c}60 \mathrm{~min} \\
\text { after CPB }\end{array}$} & \multirow{2}{*}{$\begin{array}{c}\text { Total } \\
\text { histologic } \\
\text { score }\end{array}$} \\
\hline & & & & $15 \mathrm{~min}$ & $30 \mathrm{~min}$ & $45 \mathrm{~min}$ & $60 \mathrm{~min}$ & & & \\
\hline \multicolumn{11}{|l|}{ Rolling leukocytes } \\
\hline $15^{\circ} \mathrm{C}, 20 \% \mathrm{Hct}$ & 12 & $0.4 \pm 0.4$ & $3 \pm 0.5$ & $0.8 \pm 0.7^{*}$ & $1.2 \pm 0.9^{*}$ & $0.8 \pm 1.3^{*}$ & $0.9 \pm 0.8^{*}$ & $2.1 \pm 2.1$ & $0.7 \pm 0.3$ & $1.6 \pm 0.9^{*}$ \\
\hline $15^{\circ} \mathrm{C}, 3 \mathrm{C}$ & 12 & 1 & 7 & $\pm 0.6^{*}$ & $1.0 \pm 0.9^{*}$ & $1.0 \pm 1.6^{*}$ & $1.0 \pm 0.9^{*}$ & $1.5 \pm$ & 1.5 & $1.5^{*}$ \\
\hline $25^{\circ} \mathrm{C}, 20 \% \mathrm{Hct}$ & 12 & $0.3 \pm 0.5$ & $1.7 \pm 0.5$ & $2.3 \pm 1.5^{*}$ & $2.7 \pm 1.4^{*}$ & $3.0 \pm 2.0^{*}$ & $3.0 \pm 1.6$ & $2.5 \pm 1.9$ & $1.6 \pm 1.0$ & $2.8 \pm 0.8^{*}$ \\
\hline $25^{\circ} \mathrm{C}, 30 \% \mathrm{Hct}$ & 12 & $0.7 \pm 0.8$ & $1.3 \pm 0.8$ & $2.5 \pm 2.0^{*}$ & $2.8 \pm 1.5^{*}$ & $3.0 \pm 1.7^{*}$ & & $2.0 \pm 1.6$ & $1.7 \pm 1.9$ & $1.7 \pm 1.2^{*}$ \\
\hline $34^{\circ} \mathrm{C}, 20 \% \mathrm{Hct}$ & 12 & $0.3=$ & $1.5=$ & & & & & & & $3.5 \pm 1.0$ \\
\hline $34^{\circ} \mathrm{C}, 30 \% \mathrm{Hct}$ & 12 & 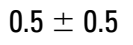 & $1.8 \pm$ & $3.8 \pm$ & - & $4.5 \pm 3.8$ & $4.3=$ & $2.7 \pm$ & $1.7 \pm 1.3$ & $3.2 \pm 1.0$ \\
\hline \multicolumn{11}{|l|}{ Adherent leukocytes } \\
\hline $15^{\circ} \mathrm{C}, 20 \% \mathrm{Hct}$ & 12 & 1.9 & $4.0=$ & 5.0 & $4.7 \pm$ & $5.0 \pm 1.6^{*}$ & 4.8 & 1.2 & 2.8 & $1.6 \pm 0.9^{*}$ \\
\hline $15^{\circ} \mathrm{C}, 30 \% \mathrm{Hct}$ & 12 & $2.3 \pm 0.5$ & $3.8 \pm 0.6^{*}$ & $4.3 \pm 1.3^{*}$ & $5.3 \pm 1.6^{*}$ & $6.3 \pm 1.6^{*}$ & $6.7 \pm 2.7^{*}$ & $5.0 \pm 0.9$ & $4.1 \pm 2.4$ & $2.6 \pm 1.5^{*}$ \\
\hline $25^{\circ} \mathrm{C}, 20 \% \mathrm{Hct}$ & 12 & $2.0 \pm 0.6$ & $3.3 \pm 1.2^{*}$ & $4.6 \pm 3.1^{*}$ & $6.8 \pm 1.5^{*}$ & $6.7 \pm 1.6$ & $7.5 \pm 2.1$ & $5.0 \pm 1.3$ & $4.0 \pm 0.6$ & $2.8 \pm 0.8^{*}$ \\
\hline $25^{\circ} \mathrm{C}, 30 \% \mathrm{Hct}$ & 12 & $1.7 \pm 1.0$ & $3.8 \pm 1.3^{*}$ & $4.6 \pm 1.5^{*}$ & $7.2 \pm 1.7^{*}$ & $7.3 \pm 1.7$ & $9.2 \pm 4.1$ & $4.8 \pm 1.7$ & $4.6 \pm 3.1$ & $1.7 \pm 1.2^{*}$ \\
\hline 34 & 12 & & $5.3 \pm 1.0$ & \pm 2.0 & $9.2 \pm 3.3$ & $10.3 \pm 3.7$ & $10.8 \pm 3.7$ & & $4.6 \pm 2.7$ & $3.5 \pm 1.0$ \\
\hline $34^{\circ} \mathrm{C}, 30 \% \mathrm{Hct}$ & 12 & $2.3 \pm 0.8$ & $5.2 \pm 1.2$ & $7.2 \pm 2.8$ & $8.9 \pm 2.6$ & $9.0 \pm 2.6$ & $9.4 \pm 3.5$ & $5.7 \pm 2.1$ & $4.2 \pm 1.3$ & $3.2 \pm 1.0$ \\
\hline
\end{tabular}

Values represent means $\pm \mathrm{SD}$. CPB, Cardiopulmonary bypass; Hct, hematocrit.

${ }^{*} P<.05$ compared with the $34^{\circ} \mathrm{C}$ group.

TABLE 2. Number of rolling and adherent leukocytes by flow rate, hematocrit, and total histologic scores

\begin{tabular}{|c|c|c|c|c|c|c|c|c|c|c|}
\hline \multirow[b]{2}{*}{ Flow rate } & \multirow[b]{2}{*}{$\mathbf{N}$} & \multirow[b]{2}{*}{ Baseline } & \multirow{2}{*}{$\begin{array}{l}\text { End of } \\
\text { cooling }\end{array}$} & \multicolumn{4}{|c|}{ Low-flow bypass } & \multirow{2}{*}{$\begin{array}{c}\text { End of } \\
\text { rewarming }\end{array}$} & \multirow{2}{*}{$\begin{array}{c}60 \mathrm{~min} \\
\text { after CPB }\end{array}$} & \multirow{2}{*}{$\begin{array}{c}\text { Total } \\
\text { histologic } \\
\text { score }\end{array}$} \\
\hline & & & & $15 \mathrm{~min}$ & $30 \mathrm{~min}$ & $45 \mathrm{~min}$ & $60 \mathrm{~min}$ & & & \\
\hline \multicolumn{11}{|l|}{ Rolling leukocytes } \\
\hline $\begin{array}{l}10 \mathrm{~mL} \cdot \mathrm{kg}^{-1} . \\
\min ^{-1}, 20 \% \text { Hct }\end{array}$ & 12 & $0.5 \pm 0.5$ & $1.6 \pm 0.5$ & $2.5 \pm 1.6$ & $3.7 \pm 3.0$ & $4.8 \pm 3.6^{*}$ & $3.8 \pm 2.3^{*}$ & $3.7 \pm 1.7$ & $1.5 \pm 1.1$ & $2.0 \pm 1.1$ \\
\hline $\begin{array}{l}10 \mathrm{~mL} \cdot \mathrm{kg}^{-1} . \\
\min ^{-1}, 30 \% \text { Hct }\end{array}$ & 12 & $0.8 \pm 0.7$ & $1.5 \pm 0.8$ & $3.0 \pm 3.3$ & $4.3 \pm 3.9$ & $4.5 \pm 3.9^{*}$ & $3.8 \pm 2.7^{*}$ & $2.0 \pm 0.9$ & $1.0 \pm 0.6$ & $3.3 \pm 0.6$ \\
\hline $\begin{array}{l}25 \mathrm{~mL} \cdot \mathrm{kg}^{-1} \cdot \\
\min ^{-1}, 20 \% \mathrm{Hct}\end{array}$ & 12 & $0.4 \pm 0.5$ & $1.4 \pm 0.5$ & $2.3 \pm 2.6$ & $3.2 \pm 2.5$ & $3.5 \pm 4.0$ & $4.0 \pm 5.0$ & $2.5 \pm 1.1$ & $1.5 \pm 1.0$ & $2.3 \pm 1.6$ \\
\hline $\begin{array}{l}25 \mathrm{~mL} \cdot \mathrm{kg}^{-1} . \\
\min ^{-1}, 30 \% \mathrm{Hct}\end{array}$ & 12 & $1.0 \pm 1.4$ & $1.5 \pm 0.5$ & $2.0 \pm 0.8$ & $2.5 \pm 1.5$ & $2.3 \pm 1.5$ & $3.2 \pm 2.0$ & $2.7 \pm 1.6$ & $2.1 \pm 1.6$ & $2.8 \pm 1.4$ \\
\hline $\begin{array}{l}50 \mathrm{~mL} \cdot \mathrm{kg}^{-1} . \\
\min ^{-1}, 20 \% \mathrm{Hct}\end{array}$ & 12 & $0.2 \pm 0.4$ & $1.3 \pm 0.5$ & $1.8 \pm 0.5$ & $1.5 \pm 0.5$ & $1.0 \pm 1.2$ & $1.2 \pm 1.2$ & $1.5 \pm 1.0$ & $0.8 \pm 1.2$ & $3.1 \pm 1.1$ \\
\hline $\begin{array}{l}50 \mathrm{~mL} \cdot \mathrm{kg}^{-1} . \\
\min ^{-1}, 30 \% \text { Hct }\end{array}$ & 12 & $0.3 \pm 0.5$ & $1.7 \pm 1.2$ & $2.1 \pm 2.1$ & $2.0 \pm 1.5$ & $1.6 \pm 1.6$ & $1.7 \pm 2.0$ & $1.5 \pm 1.4$ & $1.7 \pm 2.2$ & $1.3 \pm 0.7$ \\
\hline \multicolumn{11}{|l|}{ Adherent leukocytes } \\
\hline $\begin{array}{l}10 \mathrm{~mL} \cdot \mathrm{kg}^{-1} . \\
\min ^{-1}, 20 \% \text { Hct }\end{array}$ & 12 & $2.0 \pm 0.6$ & $3.7 \pm 1.6$ & $6.3 \pm 2.9$ & $8.2 \pm 3.8^{*}$ & $9.0 \pm 4.0^{*}$ & $8.5 \pm 3.0^{*}$ & $5.3 \pm 1.5$ & $3.8 \pm 0.5$ & $2.0 \pm 1.1$ \\
\hline $\begin{array}{l}10 \mathrm{~mL} \cdot \mathrm{kg}^{-1} \cdot \\
\min ^{-1}, 30 \% \mathrm{Hct}\end{array}$ & 12 & $2.5 \pm 0.4$ & $4.3 \pm 0.8$ & $6.5 \pm 2.9$ & $8.0 \pm 1.3^{*}$ & $8.5 \pm 1.5^{*}$ & $9.2 \pm 3.7^{*}$ & $4.7 \pm 1.5$ & $4.0 \pm 1.2$ & $3.3 \pm 0.6$ \\
\hline $\begin{array}{l}25 \mathrm{~mL} \cdot \mathrm{kg}^{-1} . \\
\min ^{-1}, 20 \% \mathrm{Hct}\end{array}$ & 12 & $1.8 \pm 0.8$ & $5.0 \pm 0.8$ & $6.6 \pm 1.5$ & $7.7 \pm 2.5^{*}$ & $7.3 \pm 3.4^{*}$ & $8.5 \pm 4.8^{*}$ & $5.0 \pm 2.2$ & $4.6 \pm 2.9$ & $2.3 \pm 1.6$ \\
\hline $\begin{array}{l}25 \mathrm{~mL} \cdot \mathrm{kg}^{-1} \cdot \\
\min ^{-1}, 30 \% \mathrm{Hct}\end{array}$ & 12 & $2.5 \pm 0.5$ & $4.8 \pm 1.4$ & $5.7 \pm 2.0$ & $7.8 \pm 3.1^{*}$ & $8.2 \pm 3.4^{*}$ & $9.3 \pm 3.7^{*}$ & $6.0 \pm 2.1$ & $5.0 \pm 3.0$ & $2.8 \pm 1.4$ \\
\hline $\begin{array}{l}50 \mathrm{~mL} \cdot \mathrm{kg}^{-1} \cdot \\
\min ^{-1}, 20 \% \text { Hct }\end{array}$ & 12 & $1.7 \pm 0.8$ & $4.0 \pm 1.1$ & $5.6 \pm 1.8$ & $5.6 \pm 1.6$ & $5.6 \pm 1.4$ & $6.2 \pm 2.2$ & $4.6 \pm 1.3$ & $3.3 \pm 0.5$ & $3.1 \pm 1.1$ \\
\hline $\begin{array}{l}50 \mathrm{~mL} \cdot \mathrm{kg}^{-1} \cdot \\
\min ^{-1}, 30 \% \text { Hct }\end{array}$ & 12 & $1.3 \pm 0.8$ & $3.5 \pm 1.0$ & $4.0 \pm 1.4$ & $5.5 \pm 1.8$ & $5.3 \pm 1.4$ & $5.6 \pm 1.9$ & $4.7 \pm 0.5$ & $4.0 \pm 2.5$ & $1.3 \pm 0.7$ \\
\hline
\end{tabular}

$C P B$, Cardiopulmonary bypass; $\mathrm{Hct}$, hematocrit.

${ }^{*} P<.05$ compared with the $50 \mathrm{~mL} \cdot \mathrm{kg}^{-1} \cdot \mathrm{min}^{-1}$ group.

.05). Poisson log-linear regression modeling detected significantly more adherent leukocytes at a temperature of $34^{\circ} \mathrm{C}$ compared with a temperature of $15^{\circ} \mathrm{C}$ and at a flow rate of $10 \mathrm{~mL} \cdot \mathrm{kg}^{-1} \cdot \mathrm{min}^{-1}$ compared with a flow rate of $50 \mathrm{~mL} \cdot \mathrm{kg}^{-1} \cdot \mathrm{min}^{-1}$. A significant inverse correlation was found between flow rate and the number of adherent and 
rolling leukocytes at 30,45 , and 60 minutes during the low-flow period (Spearman $\rho=-0.36$ to $-0.51 ; P<.05$ )

\section{Lactate}

Multiple linear regression analysis indicated that higher temperature and lower flow rate were multivariable predictors of higher venous lactate levels throughout the low-flow and rewarming periods $(P<.01)$.

\section{Neurologic and Behavioral Evaluations}

The neurologic deficit score and overall performance category showed relatively rapid recovery in all surviving animals. There was a statistically significant difference in overall performance category on POD 1 between flow rates of $10 \mathrm{~mL} \cdot \mathrm{kg}^{-1} \cdot \mathrm{min}^{-1}(1.6 \pm 0.5)$ and $50 \mathrm{~mL} \cdot \mathrm{kg}^{-1} \cdot \mathrm{min}^{-1}$ $(1.0 \pm 0 ; P<.001)$. One animal subjected to a temperature of $34^{\circ} \mathrm{C}$, a flow rate of $10 \mathrm{~mL} \cdot \mathrm{kg}^{-1} \cdot \mathrm{min}^{-1}$, and a hematocrit level of $20 \%$ died on POD 1.

\section{Histologic Assessment}

Overall, there was essentially no damage to the cerebrum. Damage was seen in the cerebellum, which was qualitatively similar but not identical to the shrunken, hypereosinophilic neurons that were used as the hallmark of hypoxic ischemic injury. In the cerebellum the brunt of the alteration was found in the Purkinje cells and the molecular layer in which their dendrites ramify. Damaged Purkinje cells exhibited tinctorial alterations, ranging from frank hypereosinophilia sometimes extending into the main branches of the dendritic arbor to more amphophilic or basophilic staining. Nuclei showed smudgy effaced cytologic detail but rarely were clearly pyknotic or apoptotic. The Bergmann glial layer overlying these damaged Purkinje cells was often hypertrophic (Bergmann gliosis). Finally, damage was assessed by making a rough visual estimate of the percentage of Purkinje cells affected in the histologic section of the vermis (chosen because it is more consistent than the horizontal sections through the hemisphere). By using these criteria, a final score of 0 to 5 was determined, which represents roughly an expansion of the 0 to 3 used for the cerebrum. In this series of piglets, no cerebella were encountered with the equivalent of a grade 4 lesion of the majority of Purkinje cells or grade 5, cavitated infarction.

The only significant multivariable predictor of histologic damage was temperature $(P<.01)$. Higher scores were found after $34^{\circ} \mathrm{C}(3.4 \pm 1.0)$ low-flow bypass compared with $15^{\circ} \mathrm{C}(2.2 \pm 1.1 ; P=.01)$ and $25^{\circ} \mathrm{C}(2.4 \pm 1.0 ; P=$ .02 ; Tables 1 and 2$)$. Hematocrit level $(P=.1)$ and flow rate $(P=.85)$ were not significant independent predictors of histologic damage. Multivariable logistic regression estimated that the risk of histologic damage was 15 times greater at $34^{\circ} \mathrm{C}$ compared with at $15^{\circ} \mathrm{C}$ or $25^{\circ} \mathrm{C}$ (odds ratio, $15 ; P<.001)$, irrespective of flow rate or hematocrit level.

\section{Discussion}

This study has demonstrated that mildly hypothermic CPB is associated with evidence of more white cell and endothelial activation in the cerebral microcirculation of piglets relative to moderately or deeply hypothermic bypass. Mildly hypothermic bypass is also associated with greater histologic injury to the brain after a 1-hour period of reduced flow rate, irrespective of whether the reduction in flow rate is mild, moderate, or severe. A severe reduction in flow rate, however, is independently predictive of greater white cell endothelial activation, irrespective of temperature. On the other hand, using $20 \%$ or $30 \%$ hematocrit does not influence the degree of white cell and endothelial activation.

\section{Hypothermia and the Inflammatory Response to Bypass}

The findings of our study are consistent with previous reports from other groups, which have documented that the inflammatory response to bypass or ischemic injury is reduced by hypothermia. In a randomized clinical trial, Chello and coworkers ${ }^{9}$ found that there was significantly greater activation of complement and neutrophils during warm relative to hypothermic CPB. Wagner and associates ${ }^{10}$ used intravital microscopy to study the microcirculation in the greater omentum during normothermic bypass relative to hypothermic bypass. The authors noted a significantly greater number of activated leukocytes with bypass at $37^{\circ} \mathrm{C}$ relative to hypothermic bypass at $28^{\circ} \mathrm{C}$. Chen and colleagues ${ }^{11}$ used intravital microscopy in a rat model with middle cerebral artery occlusion. The authors demonstrated that hypothermia reduced the accumulation of leukocytes, and this was associated with a reduced histologic inflammatory response.

The usual rationale that is stated for the use of hypothermia during $\mathrm{CPB}$ is to reduce the metabolic rate, thereby enhancing the safety of the procedure. ${ }^{12}$ In addition, hypothermia allows reduction of flow rate, which might reduce other mechanisms of inflammatory response to bypass, as well as improving intracardiac exposure through reduction of left-heart return. However, the minimum flow rate, which is acceptable at a specific temperature, needs to be better defined.

\section{Low Flow Rate and White Cell Activation}

The current study suggests that very low flow rates, such as $10 \mathrm{~mL} \cdot \mathrm{kg}^{-1} \cdot \mathrm{min}^{-1}$, increase the probability of white cell and endothelial activation. It is possible that this is an artifact in that adhesion to endothelium becomes increasingly probable at very low shear rates as a result of the reduced flow rate (ie, increased adhesion or rolling under these circumstances does not necessarily indicate a greater level of activation). An alternative explanation is suggested by a previous report from our group that examined the 
influence of hemodilution on white cell activation. Duebener and associates ${ }^{3}$ found that white cell adherence and rolling was amplified by $10 \%$ hematocrit compared with $30 \%$ hematocrit. We speculated that the reduced oxygen delivery resulting from a severe degree of hemodilution resulted in endothelial hypoxic injury and therefore activation. In the present study hematocrit levels were closer $(20 \%$ and 30\%), which might explain our failure to detect a significant effect.

\section{Histologic Injury}

The histologic damage noted in this study was different from that seen in our previous studies in which injury was prominently seen in the caudate nucleus, neocortex, dentate gyrus, and hippocampus. ${ }^{13}$ The histologic damage in the cerebellum was qualitatively different from the unequivocal hypoxic-ischemic damage we have described in earlier studies. Nevertheless, it is in keeping with the features of hypoxic-ischemic injury that have been described in the literature, ${ }^{14}$ and this seems the most likely basis. Whatever the injurious process, it clearly is exacerbated by temperature and is discernable under conditions sufficiently mild that there is no overt damage to the vulnerable neurons of the cerebral cortex, caudate nucleus, and hippocampus. The possibility that the cerebellar damage represents something more complex than response to a simple hypoxic-ischemic challenge, such as the length of arrest time, has not been excluded. We speculate that the prone position of the animal in this study relative to the supine position in previous studies might have placed the cerebellar circulation at great risk. The absence of extensive injury in other areas is consistent with previous studies by our group ${ }^{13}$ in which minimal histologic injury was found even after 60 minutes of hypothermic circulatory arrest. On the other hand, 1 hour of reduced flow at $10 \mathrm{~mL} \cdot \mathrm{kg}^{-1} \cdot \mathrm{min}^{-1}$ at $34^{\circ} \mathrm{C}$ could reasonably be considered to be a considerably greater hypoxic ischemic insult than 1 hour of circulatory arrest at $15^{\circ} \mathrm{C}$. Interestingly, however, only temperature and not flow rate emerged from the multivariate analysis as a predictor of histologic brain damage.

\section{Normothermic CPB in Clinical Practice}

Durandy and associates ${ }^{15}$ and Corno and von Segesser ${ }^{16}$ have recommended the use of normothermic full-flow bypass for pediatric cardiac surgery and have described apparently satisfactory clinical results with this approach. Although the current study did not specifically study a treatment arm that included full-flow normothermic bypass, it is important to note that even at the end of the full-flow cooling period at $100 \mathrm{~mL} \cdot \mathrm{kg}^{-1} \cdot \mathrm{min}^{-1}$, the piglets that were cooled to $15^{\circ} \mathrm{C}$ showed significantly fewer circulating leukocytes compared with piglets at $34^{\circ} \mathrm{C}$ and $25^{\circ} \mathrm{C}$. Furthermore, the number of adherent leukocytes at this time point was significantly greater at $34^{\circ} \mathrm{C}$ compared with at $15^{\circ} \mathrm{C}$ and $25^{\circ} \mathrm{C}$. Thus we believe it is important that those recommending the use of normothermic or mild hypothermic bypass study their patients carefully for evidence of increased inflammatory response relative to use of a more hypothermic technique.

It should be emphasized that it was not the goal of this study to define optimal flow conditions but rather to define minimal safe flow conditions as influenced by $\mathrm{pH}$ strategy, hematocrit, and temperature. Although there has been considerable speculation that hypothermia is per se responsible for disturbances of the microcirculation, this study suggests that in fact disturbances of the microcirculation are more likely to be found with normothermic bypass.

\section{References}

1. Carlos TM, Harlan JM. Leukocyte-endothelial adhesion molecules. Blood. 1994;84:2068-101.

2. del Zoppo GJ. Microvascular responses to cerebral ischemia/inflammation. Ann N Y Acad Sci. 1997;823:132-47.

3. Duebener L, Sakamoto T, Shinoka H, et al. Effects of hematocrit on cerebral microcirculation and tissue oxygenation during deep hypothermic bypass. Circulation. 2001;104(suppl):I260-4.

4. Forbess JM, Ibla JC, Lidov HG, et al. University of Wisconsin cerebroplegia in a piglet survival model of circulatory arrest. Ann Thorac Surg. 1995;60(suppl):S494-500.

5. Miura T, Laussen P, Lidov HG, DuPlessis A, Shin'oka T, Jonas RA. Intermittent whole-body perfusion with 'somatoplegia' versus blood perfusate to extend duration of circulatory arrest. Circulation. 1996; 94(suppl):II56-62.

6. Shin'oka T, Shum-Tim D, Jonas RA, et al. Higher hematocrit improves cerebral outcome after deep hypothermic circulatory arrest. J Thorac Cardiovasc Surg. 1996;112:1610-20.

7. McCullagh P, Nelder JA. Generalized linear models. 2nd ed. New York: Chapman \& Hall; 1989. p. 193-244.

8. Hosmer DW, Lemeshow S. Applied logistic regression. 2nd ed. New York: John Wiley \& Sons; 2000. p. 47-69.

9. Chello M, Mastroroberto P, Romano R, Ascione R, Pantaleo D, De Amicis V. Complement and neutrophil activation during cardiopulmonary bypass: a randomized comparison of hypothermic and normothermic circulation. Eur J Cardiothorac Surg. 1997;11:162-8.

10. Wagner FM, Schiller W, Dilg G, Depner C, Welz A, Lacour-Gayet F. Direct visualization of the influence of normothermic as opposed to hypothermic cardiopulmonary bypass on the systemic microcirculation in neonatal piglets. Cardiol Young. 2001;11:532-8.

11. Chen H, Chopp M, Zhang ZG, Garcia JH. The effect of hypothermia on transient middle cerebral artery occlusion in the rat. J Cereb Blood Flow Metab. 1992;12:621-8.

12. Greeley WJ, Kern FH, Ungerleider RM, et al. The effect of hypothermic cardiopulmonary bypass and total circulatory arrest on cerebral metabolism in neonates, infants, and children. J Thorac Cardiovasc Surg. 1991;101:783-94.

13. Sakamoto T, Hatsuoka S, Stock UA, et al. Prediction of safe duration of hypothermic circulatory arrest by near-infrared spectroscopy. J Thorac Cardiovasc Surg. 2001;122:339-50.

14. Thoresen M, Haaland K, Loberg EM, et al. A piglet survival model of posthypoxic encephalopathy. Pediatr Res. 1996;40:738-48.

15. Durandy Y, Hulin S, Lecompte Y. Normothermic cardiopulmonary bypass in pediatric surgery [letter]. $J$ Thorac Cardiovasc Surg. 2002; 123:194.

16. Corno AF, von Segesser LK. Is hypothermia necessary in pediatric cardiac surgery? Eur J Cardiothorac Surg. 1999;15:110-1. 


\section{Discussion}

Dr Bradley Allen (Houston, Tex). If I understood you correctly, what you are basically saying is that ischemia causes white cell activation because you only saw WBC activation with a combination of high temperature and low flow. In contrast, there was no WBC activation with either high temperature or low flow alone. Therefore ischemia causes white cell activation, and WBC activation is decreased if ischemia is avoided by reducing the temperature or maintaining higher flow rates. Is that correct?

Dr Anttila. Thank you for your very interesting question. Actually, the temperature itself was independently associated with a greater number of activated leukocytes.

Dr Allen. So you are saying that bypass at normothermia is detrimental because it causes WBC activation?

Dr Anttila. It might be. However, further investigation is needed.

Dr W. Randolph Chitwood (Greenville, NC). In your last statement, you were talking about correlating neurologic injury. Have you done additional studies that correlate with true neurologic injury? Obviously, you are worried about the oxidant component of the white cells, but how can you make that next correlation with neurologic injury?

Dr Anttila. Actually, we have a study going in which we have extended the ischemic time. In the current study we used a 60minute low-flow period, and now we are using a 2-hour low-flow period. Perhaps this will shed more light on the correlation between histologic injury and leukocyte activation.

Dr Chitwood. But you are looking at neurologic correlates, too?

Dr Anttila. Yes, of course. We found that for the neurologic deficit score, there was a correlation on the first postoperative day between flow rate and neurologic deficit score.

Dr William DeCampli (Philadelphia, Pa). Again, to look at the question of whether what you are seeing correlates with more conventional measurements of tissue ischemia, I notice in the abstract that you alluded to lactate levels without mentioning values. And I did not catch it in your talk, but did you look at metabolic and hemodynamic measures of ischemia in addition to looking microscopically at the presence of activated white cells?

Dr Anttila. Actually we did look, and there was a correlation between lactate levels and leukocyte counts. In this study we did not find a significant correlation between the number of leukocytes and histologic scores. Now we are doing a continuation of this study using a more prominent ischemic insult, and perhaps we will see more histologic findings.

Dr Irving L. Kron (Charlottesville, $\mathrm{Va}$ ). Let me ask you one question, and I think that is the key to what Dr Allen was asking: Is the white cell activation as a result of the injury or did it cause the injury?

Dr Anttila. I believe it is a consequence of ischemic damage. 